\title{
JURIDIC ANALYSIS OF USED CLOTHES CONSUMER BASED ON ARTICLE 4 CONSUMER PROTECTION AND ISLAMIC LAW PERSPECTIVE
}

\author{
Sugiharto \\ Sultan Agung Islamic University \\ rsugiharto340@gmail.com \\ Andi Aina Ilmih \\ Sultan Agung Islamic University \\ andinazuldina@gmail.com
}

\begin{abstract}
The form of legal protection for used clothing consumers based on Article 4 of Law Number 8 of 1999 concerning consumer protection and analyzes the impact of the use of used clothing by the community in the city of Semarang, related to the Thaharah aspects in Islamic Law. The results showed that the form of legal protection for used clothing consumers in the Consumer Protection Act under Article 4, namely the right of consumers to get comfort, security, and safety. This is closely related to the obligations of business actors in providing true, clear and honest information about the conditions and guarantees of goods and/or services; and the need for guidance and supervision by the government. The impact caused by used clothing is negative impact and positive impact for used clothing consumers, both in terms of economic, social and public health in Indonesia. Although in an Islamic perspective, it is recommended that people prioritize aspects of thaharah (cleanliness) as Allah SWT requires every Muslim to purify in accordance with the criteria of Allah and His Prophet.
\end{abstract}

Keywords: Consumers; Consumer Protection; Used Clothing.

\section{A. INTRODUCTION}

The ideals of the national development of the Indonesian people are to increase the welfare of the nation to create a just and prosperous society that is evenly material and spiritual. In addition, the national development goals mandated in the Pancasila and contained in the opening of the 1945 Constitution can be realized as they should. Indonesia is a legal country that gives consequences of all the daily activities of its citizens governed by law. ${ }^{1}$

Article 27 paragraph (2) of the 1945 Constitution states that every citizen has the right to obtain a decent living for humanity. To obtain a decent living as a manifestation of welfare and intelligence, it is necessary to provide sufficient quantities of good quality,

1 Ida Musofiana, Rizki Adi Pinadito, INCREASING CHILDREN'S CONSCIOUSNESS IN MOTORCYCLING OF MOTORCYCLE ON RAILWAY (study in Demak Regency), Jurnal Pembaharuan Hukum, Volume IV No. 3 September-Desember 2017, P.353-358. 
good quality goods and services at affordable prices for every citizen as a consumer ${ }^{2}$. Consumers have the right to be heard, obtain advocacy, guidance, fair treatment, and compensation to compensation if deviations occur ${ }^{3}$.

The use of the term "consumer" means consumer of goods / services. To determine which group of consumers the user depends on the intended use. ${ }^{4}$ Consumers in broad understanding include the use of goods for the benefit of other living things. Expansion of the meaning of "consumer" is intended in order to provide the widest protection ${ }^{5}$.

The rise of consumers who buy used clothes for various reasons, including cheap clothing prices and quality that is not inferior to new imported clothing. Used clothing is sometimes even preferred over new imported goods because of its higher quality even if it is used. Consumers must be able to decide for themselves how they meet the needs for good clothing and affordable prices without knowing where the used clothing came from.

Several statutory provisions governing the importation of used clothing with the highest legal umbrella are regulated in Act Number 7 of 2014 concerning Trade. In the Act, Article 47

2 Adrian Sutedi, Product Responsibility for Customer protection, Ghalia Indonesia, Bogor, 2008 P.8.

3 Gunawan Widjaja \& Ahmad Yani, Law on Consumer Protection, PT Gramedia Pustaka, Jakarta, 2003, P.29.

4 Celina Tri Siwi Kristiyanti, Consumer Protection Law,: Sinar Grafika, Jakarta, 2008, P.22.

5 Ahmadi Miru \& Sutarman Yodo, Consumer Protection Law, Raja Grafindo Persada, Jakarta, 2004, P.6. paragraph (1) states that each importer is obliged to import goods in a new condition. However, in certain circumstances the Minister of Trade may stipulate that imported goods are not new.

In addition, the Ministry of Trade has regulated the import of goods must be in a new state in the Minister of Trade Regulation No.54 / M-DAG / PER / 10/2009 concerning General Provisions in Import 2 of the Center for Foreign Trade Policy, BP2KP, Ministry of Trade as stated in Article 6 paragraph (1) which reads "Goods imported in new condition". Article 6 paragraph (2) also explains that in certain circumstances, the Minister may determine imported goods in a new condition based on; (a) laws and regulations, (b) the authority of the Minister, and / or (c) proposals or technical considerations from other government agencies.

The Ministry of Trade has not regulated the list of products that can be imported in non-new conditions as a derivative of Law No.7 of 2014 concerning Trade and also Regulation of the Minister of Trade No. 54/2009 concerning General Provisions in the Import Sector as an effort to increase legal certainty. As a result of this, used clothing commodities do not appear in LARTAS provisions that are regulated in the National Single Window (NSW) site.

This used clothing trade activity has weakened the domestic clothing industry, especially those of small and medium scale. Even the impact is felt upstream industries that produce fabrics, yarns and textile fibers. Moreover, the existence of used clothing marketing is not only limited to 
big cities, but also reaching remote areas such as inland villages (Indonesian Ministry of Trade database).

In addition to having an impact on the country's economy, used clothing can have a negative impact on public safety and safety, as stated in the Consumer Protection Act. Efforts to protect consumers from the effects of the use of used clothing, namely the existence of Article 4 of the Consumer Protection Act (UUPK) clearly states that related to the right of consumers to get comfort, security, and safety. In addition to those stipulated in Article 4 of the UUPK, Islamic Law also regulates the use of used clothing by the community.

Improvement and development of human interaction in society, both in quantity and in quality, go hand in hand with the development of human needs in modern life which is increasingly complex. Efforts to satisfy human needs can only be realized through multidimensional human interactions, namely between the user and the supplier/provider's needs, the supplier/provider's needs and industry in a variety of scales, industry providers of goods or services with the developer and producer of technology both in industry as well as communication and information. Even, human interaction is also associated with maintaining the sustainability and environmental power to support life. The development of such human interactions above, whether consciously or not, had established a variety of networks in society. ${ }^{6}$

Based on the description above, the author will state the extent of the form of legal protection for consumers of used clothing and the impact of the use of used clothing by consumers in Indonesia based on Article 4 of the Consumer Protection Act and the perspective of Islamic Law, which this study focuses on the use of used clothing by consumers, especially in the Semarang City area.

\section{B. RESEARCH METHODS}

This study uses an empirical legal research method through a legal approach and a sociological approach. Accurate data / information collection with primary data as supporting / supporting and secondary data from literature study. This primary data was obtained by surveying observations of the habit patterns of used clothing consumers and direct interviews with related parties. Whereas secondary data was obtained by conducting a literature study, both through reference books, seminar papers, legal regulations and research findings relating to the research object.

The specification of this research is descriptive research in accordance with the problems and objectives in the study. This study evaluates a number of variables relating to the problem discussed. In other words this research is only limited to describing one or more about Legal Protection. ${ }^{7}$

6 Miftah Arifin, RECONSTRUCTION OF INDONESIAN AGREEMENT LAW, Jurnal Pembaharuan Hukum, Volume II No. 2 Mei-Agustus 2015, P.245-257

7 Lathifah Hanim, PERLINDUNGAN HUKUM BAGI PARA PIHAK DALAM E-COMMERCE SEBAGAI 


\section{DISCUSSION}

1. Forms of Legal Protection for Consumers of used clothing based on Article 4 of the UUPK and the Perspective of Islamic Law

According to the World Bank, spending on used clothing and footwear in 2010 in Indonesia reached 113.4 trillion rupiah, household spending and services amounted to 194.4 trillion rupiah, overseas spending amounted to 50 trillion rupiah, and transportation costs 283.6 trillion rupiah. This shows the amount of public interest in used clothing, both for personal use and even for trade, even though there is already a ban on importing used clothing.

In the United Kingdom, second hand dress clothing was used by indie groups and students in the 1980s and 1990s. This relates to the inherent identity of used clothing, including: used clothing forms a special and unique subculture style of young people and reflects the limited financial position of young people.

In Indonesia, the biggest consumers of used clothing are young people. Although lately, used clothing is not only favored by young people with limited finances, rich people also go hunting for used clothing in several places that sell used clothing. As a result of these circumstances, the purpose of the law to achieve a balance in the legal protection is not achieved. On development, there is some suggestion that the instrument of

AKIBAT DARI GLOBALISASI EKONOMI, Jurnal Pembaharuan Hukum, Volume I No.2 MeiAgustus 2014, P.191-199. selfregulation can be effective in its enforcement. $^{8}$

Various backgrounds why the use of used clothing is increasing. There is a tendency in society to buy used clothing instead of buying new clothes because of economic needs. Buying and selling used clothing has become an option because of the growing economic need despite the prohibition to trade in used clothing.

As for the import of used clothing, it has been regulated in several statutory provisions. In Law Number 7 of 2014 concerning Trade, hereinafter abbreviated to Trade Act is a legal provision that is lex specialis. Article 47 paragraph (1) of the Trade Law states that "Every importer is obliged to import goods in new conditions". Even though there are certain conditions, the Minister of Trade can stipulate imported goods that are not new.

This Trade Law provides a basis for the government and nongovernmental consumer protection institutions to empower consumers through consumer education and education. With the current real conditions, it is necessary to empower consumers through the establishment of legislation that can protect the interests of consumers as a whole and can be effectively implemented in society.

Various safeguards carried out by the government with the aim of

8 Azharuddin, LEGAL PROTECTION FOR USERS OF INTERNET BANKING CUSTOMERS FOLLOWING CHANGES IN INFORMATION AND ELECTRONIC TRANSACTIONS LAW, Jurnal Pembaharuan Hukum, Volume VI No.1 Januari-April 2019, P.54-64. 
protecting the poor and lower middle economic groups who are still consumers of used clothing, as mandated by the constitution namely Article 34 of the 1945 Constitution stated that "the poor and abandoned children are maintained by the state".

In some developing countries to overcome unbalanced competition and improve the standard of living of the people, in general, forms of consumer protection efforts through macroeconomic policies and the application of advanced technology in certain sectors or in certain places that are not much related to people's economic activities. As for the expected results, of course it has not been satisfactory and there is still a lot of homework to do.

The legal rules related to legal protection aimed at protecting the interests of the parties, namely the Consumer Protection Act which contains legal rules that protect consumers of used clothing. Regarding the marketing and use of used clothing, it will always have a negative impact, both on the behavior of businesses and consumers of used clothing itself. ${ }^{9}$

Article 1 paragraph (3) of the Consumer Protection Act explains what is requested by the business person of every individual or business entity, whether forming a legal entity or a legal entity established and domiciled or carrying out activities in the jurisdiction of the Republic of Indonesia, both alone together through agreements to hold

9 Janus Sidabalok, Customer Protection Law in Indonesia, PT citra Aditya Bakti, Bandung, 2010, P.4. business activities in various fields of economics. ${ }^{10}$

Article 4 of the Consumer Protection Act has explained related to the right of consumers to obtain comfort, security and safety. This is also related to Article 7 regarding the obligation of business actors to provide true, clear and honest information about the conditions and guarantees of goods and / or services, as well as Article 29 and 30 regarding guidance and supervision carried out by the government. With the creation of a harmonious relationship between the government, business actors, and consumers, harmony, harmony in business activities can be achieved that not only prioritizes the profits of business actors but also prioritizes consumer safety and can achieve the objectives of the Consumer Protection Act. For this reason, consumers and business actors must know their rights and carry out their respective obligations so that the Consumer Protection Act is effective in society.

In the Trade Law states that "every importer is obliged to import goods in new circumstances", this explains the existence of a ban on imports and exports for the national interest for several reasons explained in Article 50 paragraph (2) of the Trade Law stated that: "the government prohibits the import or export of goods for the national interest with the reasons:
10 Ukie Tukinah, MODEL PERLINDUNGAN PREVENTIF BAGI KONSUMEN ONLINESHOP MELALUI KETERBUKAAN INFORMASI, Jurnal Pembaharuan Hukum, Volume II No.3 September-Desember 2015, P.388-399. 
a. To protect national security or the public interest, including social, cultural and moral community;

b. To protect intellectual property rights; and / or

c. To protect the health and safety of humans, animals, fish, plants and the environment ".

Based on Article 51 paragraph (1) and (2) of the Trade Law, it states that: "(1) exporters are prohibited from exporting goods that are determined as goods that are prohibited for export. (2) Importers are prohibited from importing goods that are designated as goods that are prohibited from being imported. "This confirms that anyone who imports and exports goods is prohibited from importing and exporting goods that are prohibited by Law.

Related to criminal sanctions for those who violate both importers and exporters, in the Trade Law Article 111 (1) states that "every importer who imports goods in a condition not new as referred to in Article 47 paragraph (1) shall be liable to a maximum imprisonment of 5 (five) year and / or criminal fine of up to $\mathrm{Rp}$. $5,000,000,000.00$ (five billion rupiah). "Violations of the import ban on used clothing will be subject to administrative sanctions and criminal sanctions in accordance with the provisions of the Trade Law, unless otherwise stipulated by the Minister of Trade.

\section{The Impact of Used Clothing by Indonesian Consumers}

The subjects of this research are consumers and businesspersons of used clothing in the city of Semarang.
The following are the results of observations and observations made by researchers at Diponegoro Stadium, Semarang. The number of used clothing consumers from the lower economic class is 50 people per week and the economic class above is 10 people per week. While the number of permanent used clothing business actors from the lower economic group numbered 10 people and the upper economic group numbered 3 people in the Diponegoro Stadium Weekly Market Semarang.

From the results of observations and observations of the authors, it shows that the middle to lower economic group is the most buying used clothing, in addition to a small portion of the upper economic group who are consumers of used clothing. The rise of consumers who decide to buy used clothing for various reasons, including the price of used clothing is very cheap and quality that is not inferior to new imported clothing. Even though the economically weak group prefers used clothing only because the price of used clothing is very cheap, consumers do not think about the impact on the national economy and on public health. This is due to the lack of public knowledge of the effects of the illegal clothing trade which can harm the country. On the other hand, the negative impact on health is related to aspects of Thaharah that need to be an important concern for the community as consumers of used clothing.

Al-Qur'an as the main source of law for Muslims has set very clearly related aspects of Thaharah. Allah Almighty requires every Muslim to purify. Clean from all impurities and 
unclean according to the criteria of Allah and His Prophet. One of them is contained in Q.S Al-Mudatsir verses 45:

"And clean your clothes. And stay away from dirty deeds and sin. "

As confirmed in Q.S Al-Baqarah verse 222:

"Verily Allah loves those who repent and those who purify themselves"

As for the authentic hadith related to thaharah in H.R. Muslim from Abu Said al-Khudri:

"Hygiene was part of faith."

In terms of health, the condition of being unfit for used clothing does not qualify for traded clothing. The national media stated that the Indonesian Ministry of Trade in collaboration with the Director General of Standardization and Consumer Protection has tested 25 samples of imported used clothing taken from stores that trade in the clothing. These samples show the presence of bacteria and fungi that multiply in these clothes.

The following author describes the impact resulting from used clothing, as follows:

a. Negative impact

1) In terms of economy

The existence of import activities and used clothing has a negative impact on the country's economy, especially in Indonesia which can lead to impeded development in the country. Increased smuggling of used clothing is one of the obstacles to development. The government is making every effort to maintain domestic economic stability. Despite facing various kinds of obstacles the country and because it is indeed a weak economic condition of consumers.

The results of the observations and observations of the authors in this study indicate that the lower middle economic group became the most consumers who buy used clothing. They buy used clothes based only on low prices without thinking about the impact that could have on the national economy. Lack of public knowledge from the illegal clothing trade can be detrimental to the country and because of the weak economic conditions of consumers.

The existence of rules that prohibit the distribution of used clothing should be a concern for the government to provide solutions to the people's economic problems. By supplying the needs of clothing with good quality and affordable prices from local products themselves, it can at least solve the problem of clothing society. On the other hand, with the availability of Indonesian local products, it can increase the country's foreign exchange and improve the country's economy.

2) Social Aspects

The used clothing trade can weaken the country's 
economy which in turn will hamper development, shut down domestic industries, disrupt the economy and national stability, and make it difficult to achieve prosperity and people's welfare. This is evident by the flood of used clothing which has resulted in the domestic apparel industry, especially those of small and medium scale experiencing a decline and even out of business. Even the impact is felt in the upstream industry which produces fabrics, yarns and textile fibers. Moreover, the marketing of used clothing is not only limited to big cities, but also to remote areas such as rural villages.

The more widespread circulation of used clothing whose price is much lower will close the market for domestic industrial clothing products. The rise of trade in used clothing can cause obstacles in the development of domestic industries, especially textile factories. This will result in a lack of stimulation for efforts to increase domestic production, which in turn will result in termination of employment for employees so as to hamper expansion of employment opportunities so that development in the social and welfare fields will experience obstacles.

3) In terms of health Other impacts that may occur are health impacts, impacts that are directly felt by end consumers or used clothing users.

This is caused by outbreaks transmitted by used clothing. If you choose so badly, consumers will get branded clothes at very cheap prices, but if they are not careful, consumers will have an impact on their health, because the used clothes can carry disease germs from previous users. The use of used clothes that do not pay attention to health aspects can lead to the development of bacteria or germs that flourish in used clothing, especially if the previous owner contracted a skin disease. For example, people abroad are reluctant to use used clothing, sadly in Indonesia they are trafficked and used alone. Though new clothes with good quality and affordable prices are still many. The use of these used clothes should be washed and sterilized before being used. Unfortunately, most consumers in Indonesia do not pay attention to this, as a result they are infected with skin diseases from the use of used clothing directly (interview with Dr. Andi Wali, one of the doctors at the Regional General Hospital).

\section{b. Positive impact}

In addition to the negative impacts, the positive effects of used clothing, especially for the lower 
middle class. The import of used clothing is very helpful for the middle and lower classes both as traders and consumers or buyers. For people who are less able to have clothes at very cheap prices, and the quality of clothing is quite good, and still suitable for use. Therefore, there are very many interested people from Indonesian society to trade and use these used clothes. Even the impact of used clothing is strongly felt by economically weak groups.

With the creation of new jobs that involve laborers, traders, and large businesses (suppliers) of used clothing, can have a positive impact on the economy of small communities. In addition, it is able to drive other business sectors, such as transportation. If imports of used clothing are stopped, the search for traders will be lost, especially for traders who do not have any other job besides trading used clothing.

\section{CONCLUSION}

From the discussion above, the following conclusions can be drawn: Forms of Legal Protection for Consumers of Used Clothing in Act
Number 8 of 1999 concerning Consumer Protection based on Article 4, namely regarding the right of consumers to obtain comfort, security, and safety. This is closely related to the obligations of business actors in providing true, clear and honest information about the conditions and guarantees of goods and / or services; and the need for guidance and supervision by the government. With the creation of a harmonious relationship between the government, business actors, and consumers, the objectives of legislation and safety of used clothing consumers can be achieved in Indonesia.

The impacts arising from used clothing are negative impacts and positive impacts for consumers of used clothing, both in terms of economic, social and public health in Indonesia. This impact can have a profound influence on the fabric of life and affect the country's economy. Even in an Islamic perspective, it is recommended that people prioritize aspects of thaharah (cleanliness) in relation to used clothing, as Allah SWT requires every Muslim to purify according to the criteria of Allah and His Prophet. 


\section{BLIBIOGRAPHY}

Adrian Sutedi, 2008, Product Responsibility for Customer protection, Ghalia Indonesia, Bogor;

Ahmadi Miru \& Sutarman Yodo, 2004, Consumer Protection Law, Raja Grafindo Persada, Jakarta;

Azharuddin, LEGAL PROTECTION FOR USERS OF INTERNET BANKING CUSTOMERS FOLLOWING CHANGES IN INFORMATION AND ELECTRONIC TRANSACTIONS LAW, Jurnal Pembaharuan Hukum, Volume VI No.1 Januari-April 2019;

Celina Tri Siwi Kristiyanti, 2008, Consumer Protection Law,: Sinar Grafika, Jakarta;

Gunawan Widjaja \& Ahmad Yani, 2003, Law on Consumer Protection, PT Gramedia Pustaka, Jakarta, 2003

Ida Musofiana, Rizki Adi Pinadito, INCREASING CHILDREN'S CONSCIOUSNESS IN MOTORCYCLING OF MOTORCYCLE ON RAILWAY (study in Demak Regency), Jurnal Pembaharuan Hukum, Volume IV No. 3 September-Desember 2017;

Janus Sidabalok, 2010, Customer Protection Law in Indonesia, PT citra Aditya Bakti, Bandung;

Lathifah Hanim, PERLINDUNGAN HUKUM BAGI PARA PIHAK DALAM E-COMMERCE SEBAGAI AKIBAT DARI GLOBALISASI EKONOMI, Jurnal Pembaharuan Hukum, Volume I No.2 Mei-Agustus 2014;

Miftah Arifin, RECONSTRUCTION OF INDONESIAN AGREEMENT LAW, Jurnal Pembaharuan Hukum, Volume II No. 2 Mei-Agustus 2015

Ukie Tukinah, MODEL PERLINDUNGAN PREVENTIF BAGI KONSUMEN ONLINESHOP MELALUI KETERBUKAAN INFORMASI, Jurnal Pembaharuan Hukum, Volume II No.3 September-Desember 2015; 